\title{
Definition of the Building Envelope: Towards a New Perspective
}

\author{
Hala Adeeb Fahmy Hanna \\ Lecturer, Department of Architecture, Faculty of Engineering, Mattaria - Helwan University \\ HALA_HANNA@m-eng.helwan.edu.eg
}

\begin{abstract}
Recently, in the light of climatic changes all over the world and technical developments, the building envelope, which is part of a physical system that includes internal and external environments and serves as a physical barrier between them, has become one of the most important studies of building science. These studies have led it to a change in building techniques, materials, designs and concepts of some building envelopes that have emerged all over the world. The building envelope materials are no longer just a cladding that have a secondary role in influencing the cultural appearance and character of the building, but turned into one of the important tools in functionality. This change has reflected in the evolution of the envelope capability to transform its main role from just a barrier to providing a comfortable indoor environment for occupants of the building, as described in all relevant definitions of the envelope, to an envelope that is also responsible towards the external natural environment to restore its quality rather than the negative effects it was causing to this environment.

Despite these changes that impose themselves, there are inefficiencies in its practice at the local level, especially in the development projects in new cities, due to many local architects are lack of knowledge of the new capabilities of the building envelopes. In this context, the study seeks to gain a deep understanding of the relationship between the building material, the building envelope and its external environment, and to highlight the growing need for such envelopes. Therefore, the research discusses this subject through two axes; the first axis examines the key definitions of the building envelope and analyzes its composition to take advantage of it in formulating the proposed definition. Followed by a study of the impact of the building envelope on the external natural environment by analyzing several international experiences. While the second axis tends to make a modest attempt to formulate a proposal for a new definition, illustrating the emerging capabilities of the envelope towards the external environment, as the definition has important theoretical and practical impacts in applying the concept that highlighted in.
\end{abstract}

KEYWORDS: Definition, Building Envelope Definition, Building Envelope Roles, External Environment, Advanced building materials and techniques. 


\section{INTRODUCTION}

\subsection{The Problem}

The main issue of the study problem is:

Many local architects lack of knowledge of the capabilities of the building envelope towards the external natural environment. This problem is due to:

1- All studies and definitions related to the building envelope address its responsibility towards the internal environment to provide different comfort levels to its occupants.

2- The technology of building envelopes materials is a forked and rapidly evolving science, and there are no specific references through which a local architect can surround this science, to employ it in building envelopes in the local environment.

As a result of this issue and its causes:

- Deficiencies in the application of building envelopes technologies and materials, and the exploitation of their characteristics by the local architect, especially in development projects in new cities sponsored by the state or private companies.

- Exacerbating many problems and threats to the external natural environment until they became the most important challenges facing our local environment today. Due to the practice of designing and constructing building envelope with traditional materials and as a result of the doubling of the size of projects and the speed at which they grow.

\subsection{Hypothesis}

The study based on several hypotheses:

- Sophisticated building envelope and what they availability of advanced properties, add a positive new effective role for the envelope towards the external environment.

- The application of modern building materials and techniques in envelopes protects environmental health and restores its quality.

- Formulating a new definition clarifying the relationship between building material, building envelope and environment helps the local architect to realize the envelope capability towards the natural environment and employ it in professional practice.

\subsection{Objectives}

The study raises some research questions related to the problem, namely:

- Have theorists addressed definitions illustrating the role of the building envelope towards the external environment?

- Does the building envelope have a role towards the external natural environment?

- Is the building material can affect the role of the building envelope?

In the context of these questions, the objective of the study lies in two main axes:

1- Studying the definitions related to the building envelope and the impact of the envelope on the external natural environment with a view to a deep understanding of this relationship.

2- A proposal to formulate a new definition of the building envelope clarifying its capability towards the external environment. Because of the definition has important implications on the theoretical and practical context in applying the concept that highlighted in. 
These objectives seek to monitor the tripartite relationship between: building material, building envelope and the external environment, to trigger a new jump-start its slogan is to protect environmental health and improve its quality.

\subsection{Methodology}

To achieve the research objectives, 3 key stages are addressed as a methodological basis:

A. Theoretical framework - literature review: focuses on recognizing what is the definition and determine its purpose and different types.

B. Deductive analytical framework: this framework tends to examine two main aspects: 1- The key definitions of the building envelope: to recognize the intrinsic nature of the envelope, devise the roles it achieves through its various elements, as well as to analyze the composition and the various parts of the definition.

2- The impact of the building envelope on the external natural environment and the study of both general and emerging environmental impacts through the analysis of many global projects, in order to identify the variables that affected the envelope and its return.

C. Theoretical thesis: a modest attempt to formulate a proposal for a new definition of the building envelope to clarify its relationship and role towards the external environment.

\section{Essence of Definition}

Before studying the basic definitions of building envelope and formulating the proposed definition, the concept of definition is studied. Where some questions arise: Is it possible to formulate a new definition differs its content from the general content of the definitions that preceded it? In other words, are there different types of definition? So that the researcher recognizes, before the start of the study, the possibility of formulating a new definition.

The definition linguistically from knew the thing, i.e., aware about it. The meaning of the definition has been termed as telling about something that requires its knowledge, knowing something else. It is also more clearly defined as providing information about something by mentioning the various characteristics that distinguish it, with a view to identify, describe and present it to others [1]. In Aristotelian logic, definition is that mental process by which we get to what the thing is, or its reality, by a phrase through which refers to the intrinsic nature of the defined thing [2].

The definition, which does not relate to the semantics as far as it relates to concepts, natures, or essences, has been named object, real or realistic definition [3]. Its purpose is to identify and clarify the essence of the defined thing by:

a- Definition with limit (analytical definition): it defines the general perceptions of the thing and mentions the subjective qualities and general intrinsic characteristics of the identifier, shared by with others of the same kind and distinguishes it from other things, which cannot imagine the thing without it. Such as the human is a speaking being.

b- Definition with drawing (descriptive definition): it focuses on the incidental (nonessential) qualities of the thing, the characteristics necessary for it and distinguish it 
from other things. I.e., defines the partial subjects by giving the apparent and external descriptions of the thing. Such as human is a laughing body.

The definition, then, is a logical approach to represent the things in mind in terms of its individual and complex loads, denominated (necessary) and non-evaluated (incidental); and these two definitions complement each other $[2,4]$.

\section{Building Envelope: Key Definitions}

More recently, several building science studies have tended to investigate the building façade, building envelope, building enclosure, and building skin, and these different terms used to label the exterior elements of a building, which are part of a physical system involving three components: the exterior environment(s), the enclosure system, and the interior environment(s) [5]. Many architectural theorists formulated several definitions illustrate the concept of this envelope.

This stage is concerned with analyzing these definitions to identify, first: Have theorists addressed definitions illustrating the role of the envelope towards the external environment? Second, to identify the roles that the envelope achieves through its various elements, and finally, analyze the composition of the definition and its various parts, to take advantage of them when preparing the formulating of the proposed definition. These definitions are different because the concept of the envelope is addressed from several aspects, where each focusing on a specific angle, namely:

\subsection{The Enclosure as a Large Bubble}

This concept has been addressed from different points of view. The building envelope as defined by City of Bremerton, Washington, is "the three-dimensional space within which a structure is permitted to occupy. Height, floor area ratio, setbacks, lot coverage and similar restrictions establish the building envelope" [6]. Whereas D. Bixby defined it from the opposite point of view, as "The exterior appearance that we first see of a building ... the boundary that separates the building from the space around it" [7]. The U.S. Department of Energy, Office of Energy Efficiency \& Renewable Energy, also presented a complementary definition of the former concept clarifies that the envelope is "the building component that separates conditioned spaces from unconditioned spaces or from outside air" [6].

While both M. Wigginton and J. Harris defined the building skin more clearly, as "the enveloping outer fabric of a building, forming a weather-protecting enclosure which keeps water out, protects us from inclement temperatures, and provides security and privacy" [8]. This definition corresponds to the vision of Le Corbusier that the outside is volatile and unclean, and that we should seal ourselves from it inside the building where everything is clean and conditioned in response [9].

\subsection{The Envelope as a moderator}

In addition to these definitions, many theorists put another concept to the envelope. C. Schittich has been defined it as "A transition between inside and outside - between the building and the urban space" [10]. While California Energy Commission more precisely 
explained one aspect of this transition by saying: "building envelope is the assembly of exterior partitions of a building, which encloses conditioned spaces, through which thermal energy may be transferred to or from the exterior, unconditioned spaces or the ground" [6]. M. Wigginton and J. Harris also described it as "the 'intelligent skin' which forms the single greatest potential controller of its interior environment, in terms of light, heat, sound, ventilation and air quality" [8]. Also M. Bigolin et al. defined it as "the area where different internal and external forces are interplay to maintain a constant internal comfortable environmental condition" [11].

From the previous review, it is noted that most of the definitions are divided into 2 parts:

1- The first part relates to the description of the envelope whether its spatial location in relation to the building or its composition / formation.

2- The second part deals with the description of the different roles and functions of the building envelope, all of which are grounded on that the envelope is the secret of inner comfort (thermal, visual and acoustic) or the quality of the internal environment. Fig.1. shows the functions included in the previous definitions to achieve the comfort.

\footnotetext{
Transparent zones -The interface between inside and outside.

As modifier of the internal conditions of the building, through the ability to control, regulate the flow of different natural external forces to internal spaces like air, heat, light and others, and / or the ability to interact and exchange internal \& external forces

Communication between the building and the surrounding environment, whether by providing a vision and a relation to the outer horizon or entering and exiting the building.
}

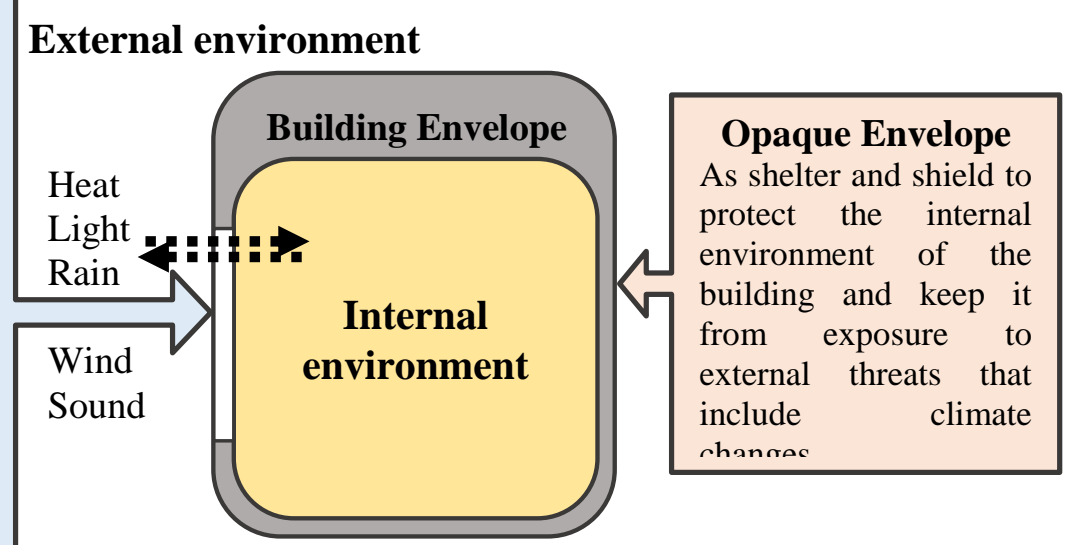

Fig.1. the building envelope and the functions achieved by its various elements, which included in the definitions. Source: the researcher.

The pervious analysis reveals several results:

1- All the definitions that have been studied focus on the inherent and the in-depth essential nature of the building envelope, which does not change no matter how the circumstances surrounding the envelope change. This nature clarifies its reality, which is shared by all the envelopes and distinguish it from other parts of the building Definition with limit.

2- It is clear from all the roles mentioned above, that although the building envelope belongs to both the internal and external environments of the building, separates, and connects these two environments at the same time, however, all definitions are entirely related to the internal environment of the building only and the impact of the envelope 
state on that environment. Where two opposing situations (impervious and permeable) coexist in a smooth and continuous relationship, in order to protect and modify the conditions of the interior, and connect with the external environment, to provide the appropriate level of comfort and quality for occupants of the building, which affects their health and productivity.

Accordingly, not all of the above-mentioned definitions address the impact of the building envelope on the external environment. In this context, many questions arise: Why did not theorists address definitions that clarify the impact of the envelope on the exterior environment? Is it because there is no impact of the envelope on this environment or its effect is negative on it? Based on these questions, the study in the next phase aims to determine the effect of the building envelope on the exterior environment.

\section{Impact of the Envelope on the External Environment}

Before studying this effect, the concept of the external natural environment surrounding the building envelope is first determined.

The external natural environment surrounding the building is a common term known as a three-dimensional space with randomly varying properties in the mass (air, moisture, etc.) and energy (heat, sound, etc.). The building envelopes are closely related to the local conditions of the site, as they are the main building element that is directly exposed to weathering and faces the different external microclimates [5]. While some researchers presented a more comprehensive and broader definition of that concept, where that environment is defined as that physical and biological surroundings, which consists of the natural resource group of air, plant, soil, climate, water, petrol and other resources, whether renewable or non-renewable, which provide the building with basic and necessary services such as raw materials and energy [12]. Others described it as a set of interlocking systems with each other to the degree of complexity that affect and determine the survival of the organisms in this world and we deal with periodically [13].

J.Straube reveals that as "the envelope interacts with both the internal and external environments; it in turn affects both environments" [5]. Accordingly, the building envelope has an impact on the external natural environment. This section is concerned with studying this effect with a view to the deep understanding of this relationship.

By examining the impact of the building envelope on the external natural environment, it was discovered that the envelope has significant impacts on this environment, which can be divided into general and emerging environmental impacts.

\subsection{General Environmental impacts}

The changes that occur for external environment systems and result from building envelopes in general. The most important of these implications are reviewed without details:

The building envelopes cause many direct and indirect environmental impacts. In Irene Lee et al, it was reported that the building envelope has significant impact on the amount and rate of resource consumption and environmental deterioration exactly like the building where it represents part of the building [14]. 
First: For resource consumption, the envelopes consume much natural resources in the form of building materials and energy throughout its life cycle (construction and renovation). Since the envelope is the single largest building element in terms of size [15], it uses the substantial amount of materials derived from many natural sources for its various components. It follows that the consumption of more embodied energy starting with the extraction and manufacture of raw materials, then the transport to the site as well as internal transport operations during construction and finally the process of demolition and transport and dispose of waste. The envelope also has a long-term impact on the ecosystem during the operation of the building, as it is responsible for the amount of heat entering into and existing from the building, it affects the high rate of energy consumption in the building $[16,17,14]$.

Second: the envelopes also contribute to environmental deterioration resulting from the use of resources. Environmental problems include air and atmospheric pollution. Where the use of energy during the manufacture and transfer of envelope materials, leads to an increase in the concentrations of certain greenhouse gases, mainly Carbon Dioxide, Sulphur Dioxide, acid gases and Oxides of Nitrogen $\left(\mathrm{NO}_{2}\right)$ that is driving global warming and climate change. In addition to the generation of waste, throughout the life cycle of the envelope, whether the construction, renovation or demolition process, substantial volume of waste is produced and disposed of in land $[18,19,14]$.

Based on the previous review, it is noted that although the envelopes provide many benefits to the internal environment, they have negative impacts on the external natural environment. It is one of the sources of terrestrial and atmospheric pollution, which is threatening the natural environment and impeding its capacity to provide a balanced ecosystem. As well, air pollution of the internal environment due to the penetration of polluted air. All of these effects lead to many risks that threaten the life of humans, plants, and animals and disrupt the right and desirable life dramatically.

It is clear from this; the theorists did not address the definitions of the building envelope that clarify its role for the external environment due to its negative effects, which constitute serious environmental issues in many countries.

\subsection{Emerging Environmental impacts}

In the context of the study of the emerging effects of the envelope on the external environment, several questions arise: if there are new effects, then there are developments that have led to that, and the question, what are the latest developments affecting the envelope that led to the emergence of these effects? Are the emerging impacts negative or positive? The next part of the study seeks to answer these questions.

Despite the continuation of the building envelope and its components for long periods largely unchanged in the concept, use and even materials, however, the enormous and rapid technological developments witnessed by the world in recent years have revolutionized in the field of building materials and brought many changes and developments in concepts, techniques and materials of envelopes. The material revolution was based on change in four levels related to weight, form, molecular composition and behavior [20]. These different variables have led to the emergence of new characteristics 
and the beginnings of the variable performance capability of the envelope, which has been associated with the emergence of new and varied roles towards the external natural environment systems. The latest global materials and techniques for envelopes and its associated emerging roles are studied in terms of the characteristics and mechanism of the material, vivid examples of the application of these techniques and materials in the envelopes, and the return on the external environment.

\subsubsection{Solar Panels (Photovoltaic modules)}

Solar or photovoltaic cells are a device in the form of cells array next to each other that generating on-site electrical energy by converting solar irradiation into electricity [21].

Characteristics and mechanism: photovoltaic conversion takes place in solar cells made of various semi-conducting materials, which are of simple construction, do not have movable parts, do not pollute the environment and display long shelf life [22]. When the sun shines, it releases large energy in the form of photons, which are absorbed and dropped by the cells on their surface, to convert it into electricity in the form of a direct current (DC), but man cannot take advantage of them. Therefore, the current flows into a special converter to convert it to alternating current (AC), which is electricity [21].

Models for some sophisticated Envelopes: Technological advances of this technique have allowed the creation of designs that integrate PV modules with traditional materials in the envelope. Applying PV cells to the envelope is termed: Building-Integrated PV, BIPV. These panels replace any of the envelope elements as spandrel glass, skylights, roofs, windows, etc., or cover the entire facade [23,24], as in the following examples:

a- Quai de Valmy 179 in Paris is the first residential building in France includes a fullfacade BIPV system, (2011), as in Fig.2a. Except the ground floor, the building's entire façade (6-storey) is clad with 7,200 solar cells integrated into glass modules [25].

b- La Seine Musicale (2017), as in Fig.2b, a music complex, near Paris, France, featuring an egg-shaped auditorium is sheltered from sunlight by a sail-like wall covered with more than $800 \mathrm{~m}^{2}$ of PV solar panels that move to follow the path of the sun [26].

c- Hexagone Balard, the new headquarters of the French Ministry of Defense, in southwestern Paris (2015), as in Fig.2c. The Balard is crowned by a roof has several peaks, like a mountain landscape, and covers with over $6,500 \mathrm{~m}^{2}$ of photovoltaic panels that provide up to $80 \%$ of the site's energy needs [27, 28].

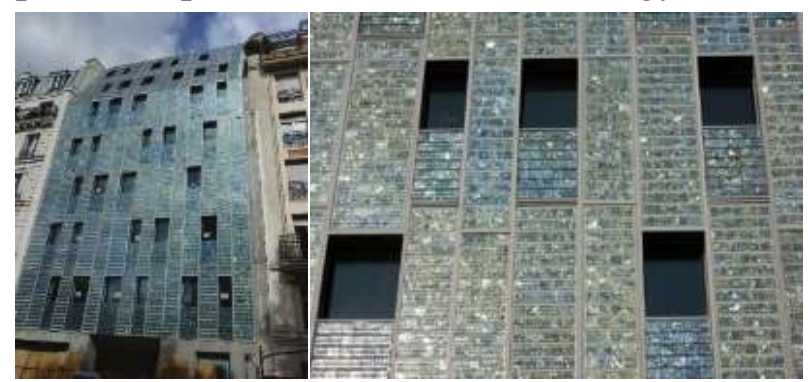

a- Quai de Valmy 179, Paris (France), [29].

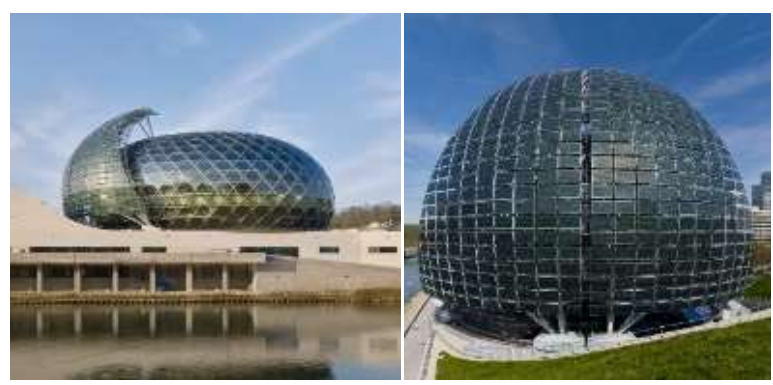

b- La Seine Musicale, near Paris [26].

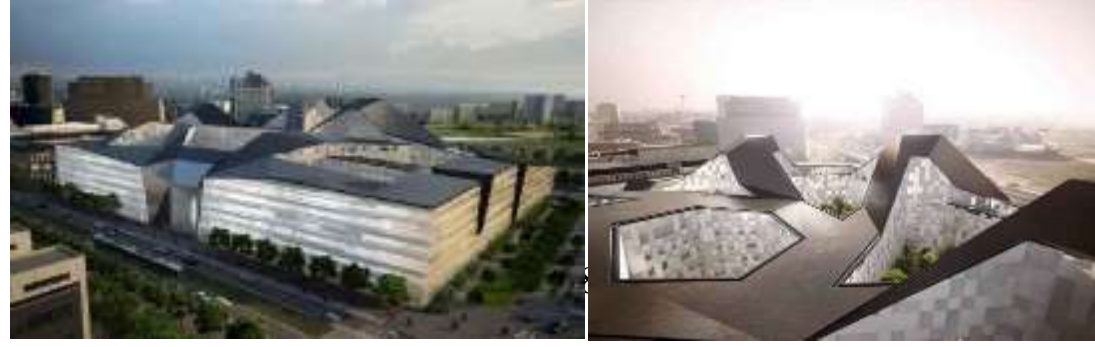


c- New headquarters of the French Ministry of Defense, Paris (France), [30].

Fig.2. installation of BIPV Solar Power System in various elements of building envelopes.

Return on the external environment from advanced envelopes: the usage of PV modules in various facade elements achieve a double effect:

- The first: as a result of its use as a contemporary building material for the envelopes rather than conventional materials, it contributes to the rational use of natural resources and saving in the use of fossil fuels, thereby reducing environmental pollution sources.

- The second impact is the clean electricity generation, which has led to the independence of buildings significantly from the electricity generated by power plants and turn them into environmentally-friendly buildings, i.e. without environmental harm, pollution, or depletion of resources $[31,22]$.

\subsubsection{Bio-based facades}

The realization of architectural researchers and designers of the importance of nature in human life has led to the emergence a new trend in façades design based on nature, known as Bio facades. It is a step towards cooperation with nature, depends on the integration of living organic systems with inorganic facades to the preservation and the constancy of balance in environment [32]. Some different techniques for Bio facades will be reviewed.

\subsubsection{Microalgae-based Bioreactors}

The word microalgae, according to botanists, denotes a variety of microscopic plants belonging to more than 20000 species, have the ability to perform photosynthesis process.

Characteristics and mechanism: microalgae are united and distinguished by a group of general features, the most important of which: they lack the known parts of the plant like roots, stems, shoots and fruits. Microalgae cultivation takes place in a much smaller areas than other plantings, also without soil or use of land resources, where they live and thrive in aquatic habitats (sea and freshwater). They have much higher and faster absorption rate of nutrients and $\mathrm{CO} 2$ than agricultural plants. In addition to its high growth rate $[33,34]$.

All of these properties enable the application of microalgae ideally in the smallest areas as buildings or urban areas that are combined with closed photo bioreactors where algae are cultivated and created the building's bio skin. These bioreactors consist of an algae panel, aluminum framing and algae growing apparatus that is comprised of intake systems for supplying CO2 and growing algae (Nutrients, etc) and discharging systems for emitting $\mathrm{O} 2$ and collecting grown algae. The growth of algae in transparent reactor depends on many favorable conditions such as light (sunlight or artificial light), liquid nutrients, $\mathrm{pH}, \mathrm{CO} 2$ and temperature, which enable algae to perform photosynthesis and reproduce regularly $[33,35]$. 
Models for some sophisticated Envelopes: bioreactors have applied as a major element in different architectural fields (building envelope, urban context). This technique transforms the static architectural component into a living and dynamic component where its appearance changes in color and becomes less transparent with the algae grow.

a- Bio Intelligent Quotient (BIQ) House, Hamburg, Germany, (2013) is the world's first building was built with a high-tech algae-powered façade, as in Fig.3a. The façade (bio skin) consists of 129 photobioreactors (PBRs) covering $200 \mathrm{~m}^{2}$. These PBRs are controlled by a centralized building management system, which forms a closed loop for energy generation and reuse [36]. The whole building is intended to be completely selfsufficient.

b- Urban Algae Folly canopy, Milan Expo 2015, as in Fig.3b, which incorporates algae cultures into its facade, is a built example of architecture's bio-digital future. This pavilion aims to generate food and fuel to raise awareness of the innovative biotechnology that leads to Feeding the Planet, Energy for Life, Oxygenate and purify the air [37].

Return on the external environment from advanced envelopes: The algae façade system plays a vital role in:

- Reducing both resource consumption (building materials and energy) and greenhouse gas emissions such as $\mathrm{CO}_{2}$ resulting from it.

- Purifying the atmospheric air and providing a healthy built environment whether externally and internally, where the façade creates an ideal environment that promotes algae growth by absorbing $\mathrm{CO}_{2}$ in outdoor environments, thus reducing its amount in the atmosphere, and generating $\mathrm{O}_{2}$ during photosynthesis [38]. In this context, Linda Graham, a professor of botany says "algae help to keep atmospheric $\mathrm{CO}_{2}$ levels stable", "algae are indispensable because they produce about half of the $\mathrm{O}_{2}$ in the earth's atmosphere" [39].

- Generating bio-fuel as a renewable energy resource after algae collection and fermentation, reducing the need to extract and burn non-renewable energy resources [40].

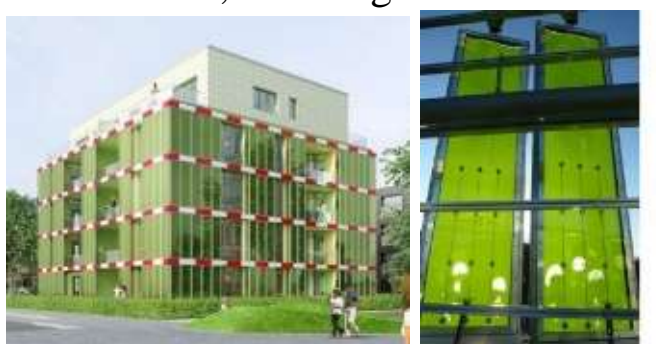

a- BIQ HOUSE, Hamburg, Germany, [41].

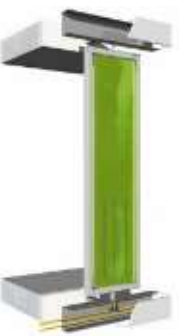

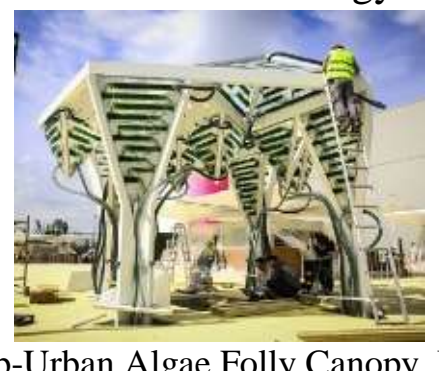

b-Urban Algae Folly Canopy, Milan Expo [37].

Fig.3. microalgae-based bioreactors application in building envelopes.

\subsubsection{Green Living Systems}

An advanced approach based on the concept of greening the environment. These systems are roofs or walls that are covered, in whole or in part, in vegetation (living organic systems), and can be incorporated into both new and existing buildings [42, 43].

Characteristics and mechanism: Vegetation is one of the important strategies of the envelope, because its diverse characteristics, including: it can live in all environments, continues to grow throughout its life, and it is the renewable source of $\mathrm{O}_{2}$ in the earth [44]. 
Greening systems adopt different technologies for vertical green or green roofs, where incorporate different types of vegetation, a growing medium, whether containing natural or artificial soil for rooting vegetation, hydroponic techniques to enable the plants to obtain nutrients through the irrigated water, and drainage into a single system [42, 45]. These systems mimic in a few centimeters what normal soil does in a couple of meters.

Models for some sophisticated Envelopes: the green living architecture is a bold concept for its cooperation with nature. From this perspective, many architects integrated it in designing their projects, which produced outstanding buildings, among those buildings:

a- Semiahmoo Library Green Wall, Surrey, Canada (2010) is the largest living wall in North America, as in Fig.4a.. The vertical garden covers $3000 \mathrm{ft}^{2}$ and consists of more than 120 unique species of plant, including ground covers, large perennials, shrubs and small trees. This diversity of plant is an urban oasis for bees, butterflies and hummingbirds [46].

b- UWC Dilijan College (2014), is the first BREEAM certified building in Armenia, as in Fig. $4 \mathrm{~b} .4750 \mathrm{~m}^{2}$ of green wavy roofs and $1500 \mathrm{~m}^{2}$ of living walls on the main facade cover the academic building to tie it to its surroundings nature. Non-standard lawn and native plants were used so that the building changes its appearance as the seasons change [47].

c- Singapore-based WOHA designed the Kampung Admiralty building (2017) unites a mix of public facilities and services (healthcare, social, commercial amenities and social housing) beneath one roof. This is topped by a roofscape of staggered terraces covered in local plants, which functions as a park to encourage residents to sit together and socialize, as in Fig.4c. The amount of green space greater than the building's overall footprint [48].

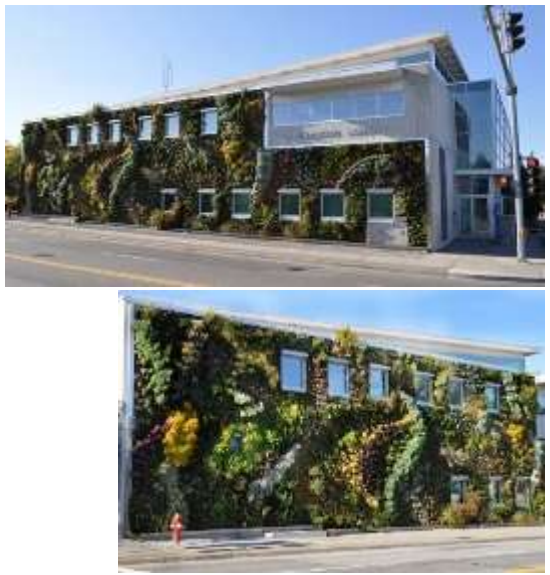

a- Vertical garden, Semiahmoo Library, garden,

Surrey. (Canada), [46].
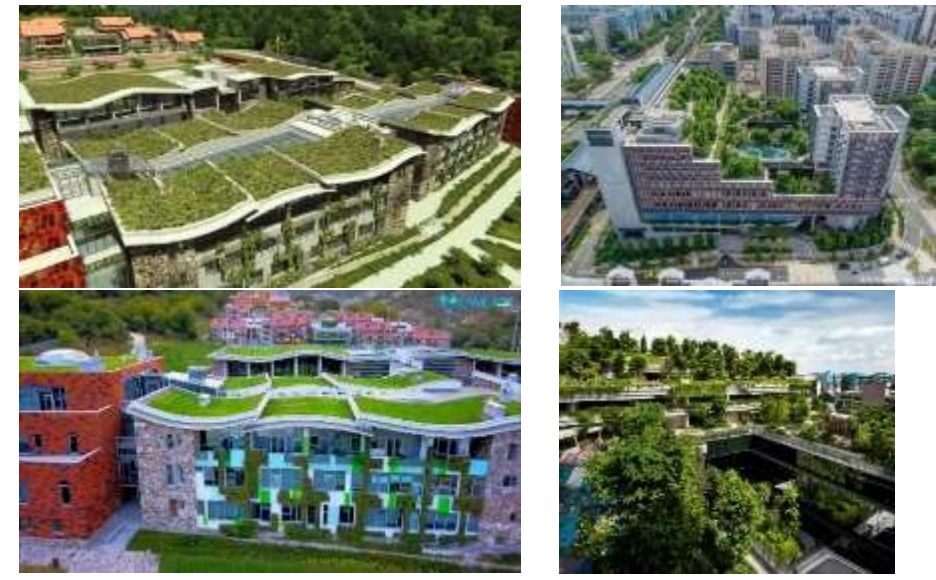

b- Living green walls and roofs, UWC c- Multilevel green roof Dilijan College, Armenia, [49,50]. Kampung Admiralty, Singapore[51].

Fig.4. Covered building envelopes with various green living systems. 
Return on the external environment from advanced envelopes: Green living systems strategy has significant impacts on the urban environment far more than its aesthetic effects. Where vegetation plays important roles in [52,53,54]:

1- Mitigation of urban heat island effects (UHI): Green systems reduce UHI effect and the overheating of cities that arise due to large expanses of pavement and rooftops absorb solar radiation and re-radiate it as heat. Researchers at the Welsh School of Architecture, Cardiff University, concluded that green systems decrease urban temperatures and cool the climate around a building in a city throughout the day by $3.6-11.3^{\circ} \mathrm{C}$.

2- Air quality Control: green walls contribute to better air quality through their ability to:

a- Filtration of air pollutants: Vegetation removes pollutants directly and indirectly. Plants absorb many gaseous pollutants through their stomata, intercept particulate matter (PM) (smoke, dust) with their leaves, and are capable of breaking down certain organic compounds such as poly-aromatic hydrocarbons in their plant tissues or in the soil, lowering the air pollutant concentration. In addition, Studies have shown that vegetation can trap up to $95 \%$ of heavy metals in the local atmosphere.

b- Carbon Dioxide/Oxygen Exchange: Through the process of photosynthesis, vegetation sequester carbon and produce oxygen, humidify and oxygenate the air [52].

c- Sterilization: green coverage helps to reduce the bacterial content in the air. Some plant species sterilize and inhibit the bacteria and pathogenic microorganisms in their living environment and improving the urban environment's ecological value.

In addition, green systems provide a significant amount of insulation as protect a facade from UV and thus reduce energy demand for building cooling. Energy saving leads to reduce the emission of pollutants from coal-fired power plants.

3- Stormwater management: Green systems absorb rainwater, keeping it off the streets, therefore reducing stormwater run-off in urban environments and the stress on sewage systems. Water stored by the substrate, then taken up by the plants and returned it to the atmosphere through the process of transpiration and evaporation.

4- Enhancement of biodiversity of an urban area: green cover represents a deliberate effort to incorporate living material into a building and create a habitat in which there is greater biodiversity and less imbalance between humans and other fauna.

\subsubsection{Reclaimed and Recycled materials}

Many building materials available are manufactured from recyclable materials and are used as substitutes for conventional materials. These materials are divided according to their nature into: non-organic such as concrete, metal, stone, glass, plastic, tires and so on; and organic like wood, clay (brick - tile) and others that can be recycled and used for different purposes in the construction industry including envelopes [55].

Characteristics: due to the multiplicity of recycled materials and the different methods of their generation and use, the physical or chemical characteristics vary from one material to another, from place to place and from time to time depending on the location and type of construction projects [56]. Despite this contrast, V. Sumateja emphasized that recycled materials are just as strong and durable as new materials.

Models for some sophisticated Envelopes: The use of recycled materials in building envelopes began to gain momentum, as architects have created many ideas from the 
various choices of recycled materials that reflect the different ways of managing waste, notably:

a- The stratified facade of the new SOS Children's Villages Lavezzorio Community Center, (2008), as in Fig.5a. utilized leftover concrete aggregate (waste) from construction sites around Chicago as a major component of the building. The facades feature the different types of aggregate that express about how and when the concrete was poured [55].

b- Architect Stephane Malka created a new, versatile skin for an existing building, AME-Lot, a student residence, Paris (2011), as in Fig.5b. The façade relies entirely on recycled shipping pallets as its construction material. Wooden pallets held using horizontal hinges; act as a movable membrane to provide privacy, natural ventilation or sun shading. [57].

c- Rotterdam house, the Netherlands, (2016), as in Fig.5c. The bricks formed the façade that was designed by Architectuur Maken who utilized a company that gathered 15 tons of waste and rubble from around the country, including ceramics, glass and clay, to create the caramel-toned bricks. This project is the first application of WasteBasedBricks [58].

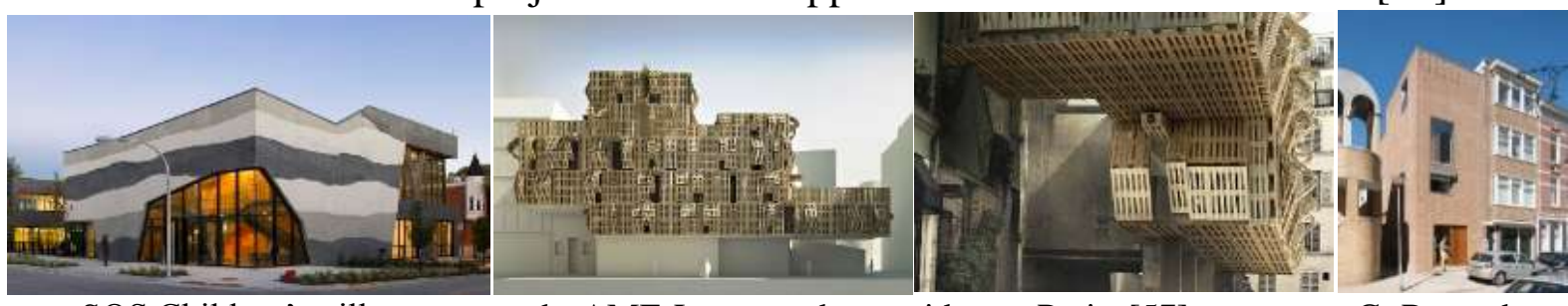

a- SOS Children's villages

b- AME-Lot, a student residence, Paris, [57].

C- Rotterdam Lavezzorio Community Center, [55]

house, the Netherlands, [58]

Fig.5. building envelopes built out of recycled material.

Return on the external environment from advanced envelopes: recycled materials in envelopes have positive effects on the external environment, namely the preservation of the natural resources. Thus reducing environmental impacts associated with new materials extraction and processing; the most important are lowering energy requirements, and environmental pollution. In addition, reducing the amount of waste in the landfills [59, $60]$.

\subsubsection{Catalytic materials}

These materials are based on photo-catalytic oxidation process, in which specific nanoparticles - usually titanium dioxide $\left(\mathrm{TiO}_{2}\right)$ - are mixed into the envelope paints or added to all materials used in various elements of the envelope due to its transparency [61].

Characteristics and mechanism: $\mathrm{TiO}_{2}$ is the most advanced oxidation Technologies (AOT) applied to water and air purification as the best photocatalyst, besides its low cost, as well as its unique properties such as non-toxic and water insoluble, making it attractive for environmental applications. During the purification process, this substance works on the degradation of harmful organic and inorganic compounds as anti-bacterial growth. It depends upon the excitation of the $\mathrm{TiO} 2$ surface by UV light illumination or some LED lights, which stimulates some carriers that interact with the external pollutants and 
accelerate their oxidation, Which leads to their degradation and transformation into harmless compounds, without consuming the material in this process [62].

Models for some sophisticated Envelopes: There are numerous examples of envelopes that have been used catalytic materials, among them:

a- The global boxer, Muhammad Ali Center (MAC), Louisville, Kentucky, USA, 2005, as in Fig.6a. The design of its facades is characterized by using 30*60 Ceramic tiles, equipped with a photocatalytic surface coating, to air-purifying, breaking down pollution and exhaust gases from vehicles and industry in the surrounding atmosphere [63].

b- 570 Broome, a 25-story condominium building, located next to New York's trafficridden Holland Tunnel, in New York City, 2018, as in Fig.6b. The façade is crafted from sintered stone panels sprayed with PURETi's "aqueous and titanium dioxide nanoparticlebased treatment that provides the building with the air-purifying power of 500 trees [64,
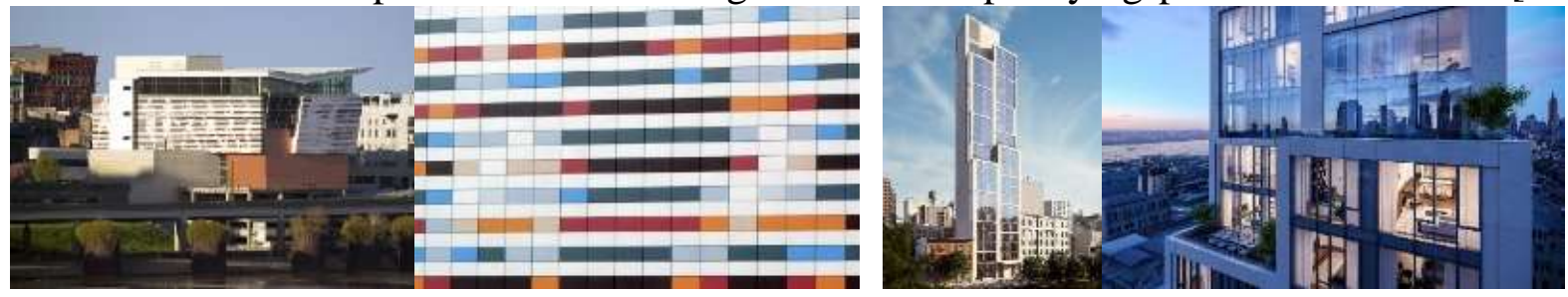

65].

a- Muhammad Ali Center, Louisville, USA, [66]. b- New York's 25-Storey Luxury Condo 570 Broome, [67].

Fig.6. use the photocatalytic material in building envelopes to give them air purification property.

Return on the external environment from advanced envelopes: this substance with advanced properties improves the characteristics and functions of the envelopes in which they are integrated. As it works to improve air quality by removing significant amounts of environmental pollutants that harm human health, namely:

- Nitrogen Oxides (NOx) - major component in the formation of acid rain, ground level ozone (smog), and certain toxic chemicals - Sulfur Oxides (SOx), component to acid rain and the formation of many harmful sulfates and other products - Volatile Organic Compounds (VOC's), such as benzene and toluene - Ammonia (NH3) - Carbon Monoxide - Organic chlorides, aledehydes, polycondensated aromatics, among others. In addition, Photocatalytic envelopes reflects much of the sun's heat, which reduces the heat gain of the structural surfaces during the summer seasons and reduces the air temperature in urban environments, and as a result, reduces the amount of smog [68].

Building envelopes have been examined in the previous review reveal that we are in front of a real phenomenon and reality of a new type of envelopes that is no longer talk about it as a fiction, moving away from the traditional fashionable type of building envelops. As Albert Einstein had previously pointed out, "The world we have created today as a result of our thinking thus far has problems that cannot be solved by thinking the way we thought when we created them." [69]

\section{Proposal to Add a New Definition of Building Envelope}

In any scientific conception of a subject, it begins with some knowledge about it, which the human mind gradually discovers (characteristics, roles, qualities, relationships, 
etc.), and this knowledge leads to its definition and distinguish it from others [2]. According to this scenario, based on the aim of the research at this phase that is to propose a new definition of the building envelope, the researcher first seeks to discover and determine emerging roles of envelopes in relation to the external natural environment. But before the discovery of new roles, the researcher stops a little to determine the desired goal or what are the feasibilities and benefits behind the proposal to formulate a new definition?

\subsection{The aim of formulating a new definition of the envelope}

The idea of the research (formulation of a proposal for a new definition) arose from the researcher's vision and his perception that the definition has important implications in the theoretical and practical context, which lies in:

1- In theory:

- Clarify the essence of the building envelope as related to the external natural environment and put it in its proper context.

- Assists in putting local architects on a common knowledge ground with international architects about the emerging role of the building envelopes, to represent it in mind to reach the intellectual development.

2- In practice:

- To be the definition an entry to guide, push and unify the efforts of local architects to adopt and employ the various advanced strategies and methods of building envelopes judging from the importance of the emerging role in facing the pressing environmental problems that beset the local environment, as well as to reach civilized development.

\subsection{Emerging roles for building envelopes}

In accordance with the objective of this phase of the research described above, the research tends to discover and determine the emerging roles and functions of building envelopes in relation to the external natural environment and its nature, is it negative, lead to the aggravation of the environmental problems and issues, or positive? To determine the possibility of formulating the proposed definition or not. The roles are determined by a deductive analytical study of what has been reached of the knowledge during the detailed review in the previous phase of some of the latest global materials and technologies for building envelopes, and the return associated with each of them, as shown in table (1).

Table 1: an analytical study of the latest building envelopes techniques and associated return, to determine the emerging roles of envelopes towards the external natural environment. Source:

researcher.

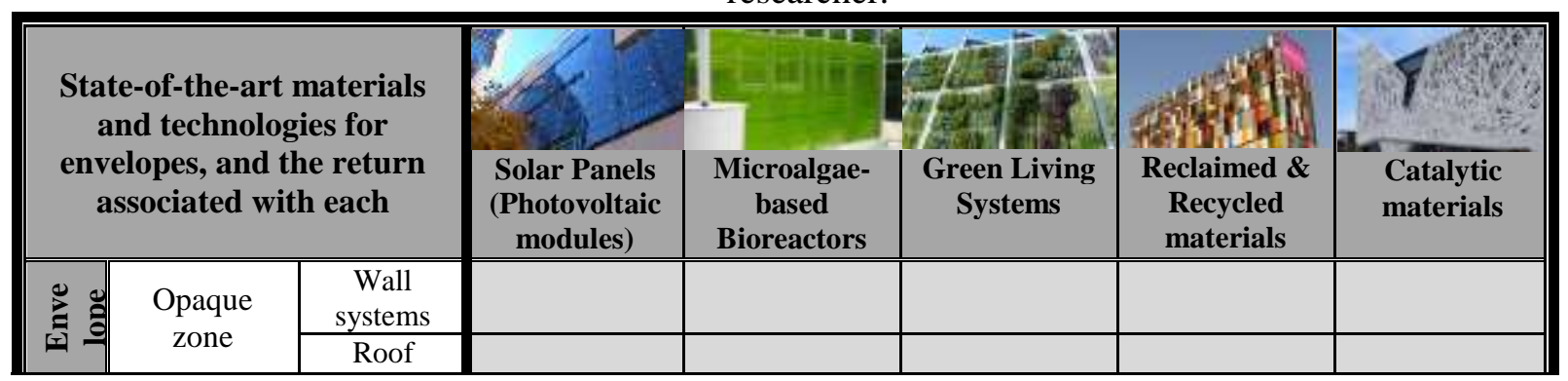




\begin{tabular}{|c|c|c|c|c|c|c|c|c|}
\hline & \multirow{2}{*}{\multicolumn{2}{|c|}{$\begin{array}{c}\text { Transparent } \\
\text { zones }\end{array}$}} & systems & & & & & \\
\hline & & & $\begin{array}{l}\text { Windows } \\
\text { and doors }\end{array}$ & & & & & \\
\hline \multirow{11}{*}{ 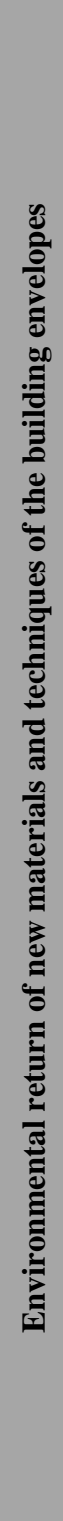 } & \multirow{4}{*}{ 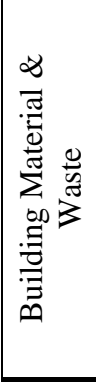 } & \multicolumn{2}{|c|}{ Raw Materials } & $\begin{array}{l}\text { Reduce the } \\
\text { use }\end{array}$ & Reduce usage & & $\begin{array}{l}\text { Rationalize } \\
\text { their use }\end{array}$ & \\
\hline & & \multicolumn{2}{|c|}{$\begin{array}{l}\text { Used building } \\
\text { materials }\end{array}$} & & & & $\begin{array}{l}\text { Reuse and } \\
\text { Recycling of } \\
\text { them }\end{array}$ & \\
\hline & & \multicolumn{2}{|c|}{ New materials } & $\begin{array}{l}\text { Used as an } \\
\text { alternative } \\
\text { material }\end{array}$ & $\begin{array}{l}\text { Used as an } \\
\text { alternative } \\
\text { material }\end{array}$ & & $\begin{array}{l}\text { Used as an } \\
\text { alternative } \\
\text { material }\end{array}$ & \\
\hline & & \multicolumn{2}{|c|}{$\begin{array}{l}\text { Terrestrial } \\
\text { Pollution }\end{array}$} & & & & $\begin{array}{l}\text { Reduce its } \\
\text { quantity }\end{array}$ & \\
\hline & \multirow[b]{2}{*}{ 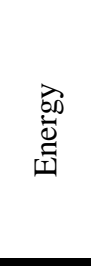 } & \multicolumn{2}{|c|}{$\begin{array}{c}\text { Fossil Fuel } \\
\text { Energy }\end{array}$} & $\begin{array}{l}\text { Large savings } \\
\text { in the use }\end{array}$ & $\begin{array}{l}\text { Reduce } \\
\text { consumption }\end{array}$ & $\begin{array}{l}\text { Demand } \\
\text { reduction }\end{array}$ & $\begin{array}{l}\text { Energy } \\
\text { conservation }\end{array}$ & \\
\hline & & \multicolumn{2}{|c|}{$\begin{array}{c}\text { Renewable } \\
\text { Energy }\end{array}$} & $\begin{array}{l}\text { Clean power } \\
\text { generation }\end{array}$ & $\begin{array}{l}\text { Generating } \\
\text { biofuels as a } \\
\text { renewable } \\
\text { energy } \\
\text { resource }\end{array}$ & & & \\
\hline & \multirow{4}{*}{ 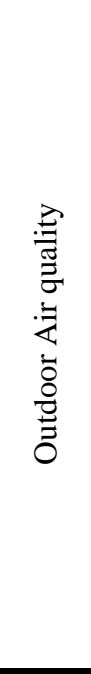 } & $\begin{array}{r}\text { Gree } \\
\text { En } \\
\text { At } \\
\mathrm{P} \\
\end{array}$ & $\begin{array}{l}\text { nhouse gas } \\
\text { issions \& } \\
\text { nospheric } \\
\text { ollution }\end{array}$ & Reduce it & Reduce it & Reduce it & Reduce it & \\
\hline & & \multicolumn{2}{|c|}{ Air Pollutants } & & $\begin{array}{l}\text { Absorb } \mathrm{CO}_{2} \& \\
\text { Reduce its } \\
\text { concentration }\end{array}$ & $\begin{array}{l}\text { Absorb many } \\
\text { air pollutants } \\
\text { and } \mathrm{CO}_{2} \& \\
\text { Reduce their } \\
\text { concentration }\end{array}$ & & $\begin{array}{l}\text { Absorb } \quad \& \\
\text { remove a } \\
\text { large amount } \\
\text { of air } \\
\text { pollutants and } \\
\text { Reduce their } \\
\text { concentration }\end{array}$ \\
\hline & & \multicolumn{2}{|c|}{ Oxygen } & & $\begin{array}{l}\text { Generate } \mathrm{O}_{2} \\
\text { \& increase its } \\
\text { ratio in the } \\
\text { atmosphere. }\end{array}$ & $\begin{array}{l}\text { Produce } \mathrm{O}_{2} \& \\
\text { increase its } \\
\text { ratio in the } \\
\text { atmosphere. }\end{array}$ & & \\
\hline & & \multicolumn{2}{|c|}{$\begin{array}{l}\text { Temperature } \\
\text { around the } \\
\text { building }\end{array}$} & & & Reduce it & & Reduce it \\
\hline & 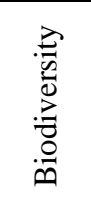 & \multicolumn{2}{|c|}{$\begin{array}{l}\text { Diversity in the } \\
\text { elements of the } \\
\text { natural } \\
\text { environment }\end{array}$} & & $\begin{array}{l}\text { The diversity } \\
\text { of genetic, } \\
\text { ecosystems } \\
\text { and vital } \\
\text { processes. }\end{array}$ & $\begin{array}{l}\text { Promote } \\
\text { harmony with } \\
\text { the } \\
\text { environment }\end{array}$ & & \\
\hline
\end{tabular}

From the previous analytical study table, it is noted that through technological advances in innovating new building techniques and materials, and changing the surficial properties of building envelopes, the performance of envelopes has evolved. The roles and functions of the building envelopes are no longer confined to their internal environment, as mentioned above, but extended to include their external natural environment. Where they have become achieve many positive new roles and functions - direct and indirect- in relation to the external natural environment, both at the level of the space surrounding the building and the pool of intertwined natural resources and systems, including: as in Fig.7.: 


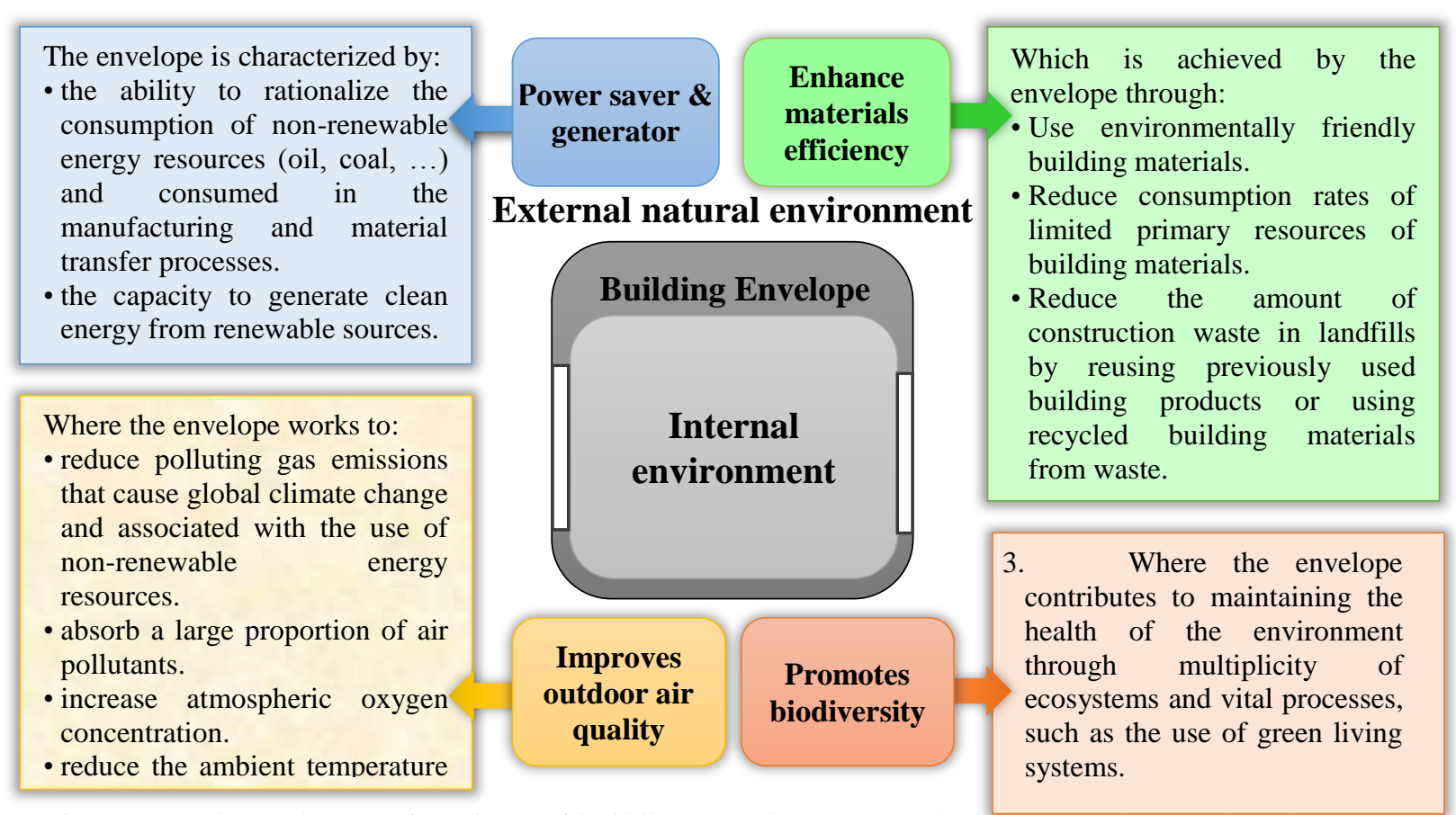

Fig.7. emerging roles and functions of building envelopes towards the external natural environment.

Source: the researcher.

These results show that the design of the envelopes becomes meets a large number of performance parameters related to the external natural environment that were not given a great deal of consideration in the past. It also shows what tomorrow facades can do, as it will be much more than just a representative element of the building's image and an aesthetic cladding that provides a degree of environmental separation to protect against rain and cold.

\subsection{Proposal for the new definition of the building envelope}

As a result of the emergence of positive new roles for the envelopes towards the external environment mentioned above, the researcher suggests expressing these roles through a new, clear and precise definition declaring the emerging nature of envelopes. As described in the definitions mentioned at the beginning of the study that reveal the different roles of the envelope towards the internal environment of the building. In this context, the researcher presents a modest attempt to formulate the new definition proposal.

But before formulating the proposal, the characteristics and type of that definition, which the researcher deduced from all the studies described above are determined. Where the study highlighted that the emerging roles are not of the intrinsic characteristics of the envelope, but are incidental attributes distinguish some envelopes from others, especially those that use advanced technologies. In addition, these roles are from the necessary characteristics, because of its very important positive impact on the external environment of the envelope. Based on the types of definition described at the beginning of the study, it is clear that the proposed definition is of the descriptive definition type (definition with 
drawing), where it will present a partial theme for the envelopes, in which the focus is on describing the emerging nature of the building envelopes that have become a phenomenon.

Notes from all the emerging roles and functions described above. That we are in front of a new form of envelopes have a responsibility towards the environment: preserve its resources by achieving efficiency and moderation in use, enhance the quality of its air, reduce its waste, and harmonize with its natural beauty; i.e. works to improve the quality of the external natural environment. Which requires the formulation of a new definition reflecting the new realities of the envelopes, to serve as a conduit for enhancing the quality of life in the external natural environment.

From this point of view, the attempt to formulate the new definition proposal is that:

Building envelope: a composition of the elements of the building shell, which provides an effective contribution to the preservation of the external natural environment and improve its quality, with regard to the consumption of natural resources, terrestrial and atmospheric pollution, and biodiversity, as a result of its use of environmentally friendly materials and technologies.

This proposed definition is an entry to know the aspects of dealing with the environment, also a call to deal with it better through the interrelationship between the building envelopes, the materials used in it and what surrounds it. If adopted, it will provide an opportunity for the architect to produce multiple designs that respect the environment, i.e. taking into account the different environmental impacts for these envelopes.

\section{Conclusion}

Based on what was previously reviewed, several conclusions can be drawn, including:

o Definition is a logical approach to represent the thing in the mind, in terms of its individual and complex loads, denominated (necessary) and non-evaluated (incidental). It is intended to provide information about something by mentioning the various characteristics that distinguish it, with the aim of identifying, describing and presenting it to others.

o Although the building envelope is inherently an intermediate surface between the internal and the external environment, however, all definitions of the envelope relate to the internal environment of the building only and focuses on its intrinsic nature and it's the secret of interior comfort or quality of the internal environment. Where the envelope acts primarily as a barrier to protect the internal environment, in addition, it acts as an interface between the two environments to exchange climatic conditions between them and to communicate with the external environment.

o The exciting technology developments witnessing by the contemporary world in the field of building materials and technologies, which have incorporated into the building shells, led to many radical changes, the most important of which are:

- The conventional methods of building envelopes change which causes many negative effects on the external natural environment. 
- A new identity has emerged for building envelopes based on multidisciplinary scientific principles and analysis of the different characteristics (physical chemical - thermal - ...) of the building materials.

- Evolution of the building envelopes performance, where many new roles and functions of the envelopes have emerged towards the external environment, which contribute to solving many problems related to the environment.

o The new functions of building envelopes support access to preserve the environment and improve its quality, which is to promote the efficient use of primary resources of energy and building material, reduce air pollutants and environmental damage to waste, besides providing harmony with nature.

\section{Recommendations}

o The necessity of awareness among the specialists in the field of architecture about the emerging environmental impacts of building envelopes on the external environment, and the role of sophisticated technologies and building materials in achieving these effects. In addition to their familiarity with the different characteristics of these materials, through holding seminars or lectures to maximize the use of them in the local environment when designing envelopes.

o The need to prepare cooperation plans with advanced states in the use of sophisticated construction techniques in the building envelopes that have a positive impact on the environment, in order to take advantage of their scientific progress in this field.

o Local orientation towards keeping up with advanced technologies and global developments in the building envelopes that preserve the environment and improve its quality, through raising awareness with the economic and environmental return on society and the natural environment and thus on human health and life. Besides providing economic incentives for the parties involved in the construction process, whether institutions or individuals.

o The urgent need for rehabilitate existing building envelopes using new techniques and materials to improve the quality of the natural environment, by providing all means of support and the necessary facilities for pilot projects of rehabilitation.

o Introducing a new legislation system stipulating not granting licenses for any new building, unless after ascertaining that it contains an envelope affects positively on the external natural environment.

o Encourage and support the production of unconventional building materials, for example from recycling of construction waste or others with local technology, to rationalize the consumption of non-renewable raw materials, or to be an alternative source of materials' non- available locally.

\section{References}

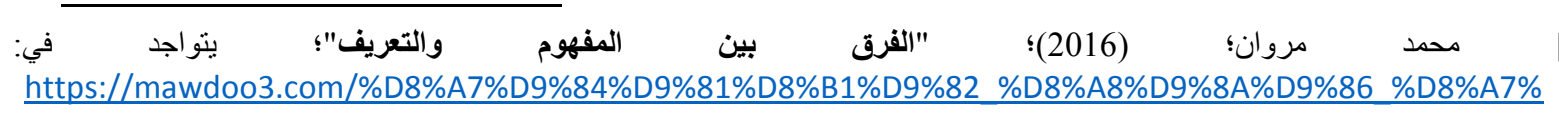


D9\%84\%D9\%85\%D9\%81\%D9\%87\%D9\%88\%D9\%85 \%D9\%88\%D8\%A7\%D9\%84\%D8\%AA\%D8\%B9\%D8\%B1\%

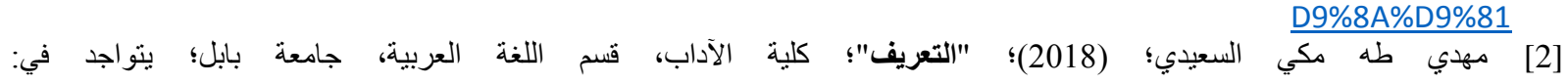
http://www.uobabylon.edu.iq/uobColeges/lecture.aspx?fid=8\&depid=2\&lcid=78366

[3] كامل محمد محمد عويضة؛ (1993)؛ "لافيج فتجنشتين - فيلسوف الفلسفة الحديثة" جزء-45 / سلسلة أعلام الفلسفة؛ دار الكتب العلمية،

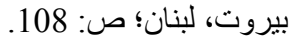

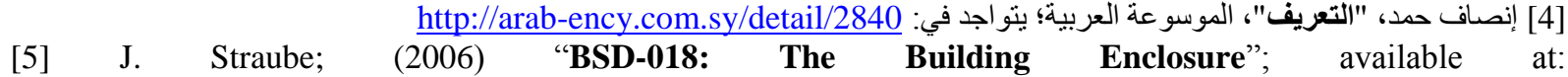
https://www.buildingscience.com/documents/digests/bsd-018-the-building-enclosure_revised, (Accessed 195-2019).

[6] ("Defined Term”); "Building Envelope"; available at: https://definedterm.com/building envelope; (Accessed 20-5-2019).

[7] D. Bixby; (2009); "Building Skin as a Connector - Not a Representation"; $7^{\text {th }}$ International Space Syntax Symposium, P: 010:1.

[8] M. Wigginton \& J. Harris; (2002); "Intelligent Skins"; Butterworth-Heinemann, P: 27, 3.

[9] S. Lee \& S. Holzheu; (2011); "Building Envelope as Surface"; chapter in the book "Aesthetics of Sustainable Architecture"; 010 Publishers, Rotterdam, P: 124.

[10] C. Schittich; (2012); "In Detail: Building Skins"; Walter de Gruyter, P: 9.

[11] M. Bigolin, L.C. PINTO Da Silva Filho \& H. Elkadi; (2017); "Natural Hazards and Building Skin: Systematic Literature Review"; $13^{\text {th }}$ international postgraduate research conference 2017, P: 937.

[12] سري قاسم امين \& غادة غالب عبد الوهاب، (2015)، "المؤشرات البيئية للفضاءات الخارجية في ابنية المستشفيات"، وقائع مؤتمر

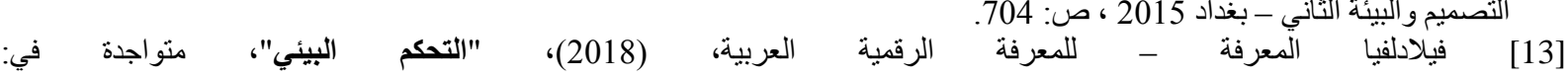
http://arknowledge.net/2018/11/28/\%D8\%A7\%D9\%84\%D8\%AA\%D8\%AD\%D9\%83\%D9\%85\%D8\%A7\%D9\%84\%D8\%A8\%D9\%8A\%D8\%A6\%D9\%8A/

[14] I. Lee \& R. Tiong; (2007); "Examining the Role of Building Envelopes towards achieving Sustainable Buildings"; International Conference on Whole Life Urban Sustainability and its Assessment, Glasgow; P: 1$2,10,11$.

[15] A. Ahmed Hassan; (2018); "Design Innovation and Sustainable Building Envelope"; The International Engineering Conference \& Exhibition,; P: 6.

[16]M. Monkiz; P.F.G. Banfill \& G. F. Menzies; (2009); "Life-Cycle Assessment and the Environmental Impat of Buildings: A Review"; Sustainability 2009; P: 676.

[17]J. Ayarkwa; A. Acheampong; J.K. Hackman \& K. Agyekum; (2014); "Environmental Impact of Construction Site Activities in Ghana"; Africa Development and Resources Research Institute (ADRRI) Journal; vol.9, no.9(2), June, 2014; P: 3.

[18]WD Re-Thinking Ltd; (2010); “The Impacts of Construction and the Built Environment"; WILLMOTT DIXON; P: 2, 3.

[19]M. Mbala; C. Aigbavboa \& J. Aliu; (2018); "Reviewing the Negative Impacts of Building Construction Activities on the Environment: The Case of Congo"; International Conference on Applied Human Factors and Ergonomics; P: 6.

[20] علاء الدين السيد، أسعد على سليمان \& \& عادل عبد الحميد رضوان، (2015)، "مواد البناء الأكية والنانوية ـ مدخل لزيادة كفاءة وتكامل

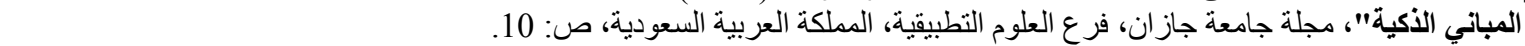

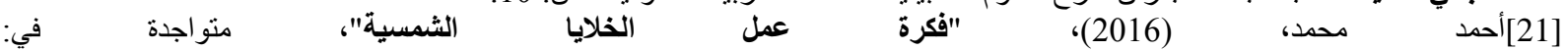

https://mawdoo3.com/\%D9\%81\%D9\%83\%D8\%B1\%D8\%A9 \%D8\%B9\%D9\%85\%D9\%84 \%D8\%A7\%D9\%8

4\%D8\%AE\%D9\%84\%D8\%A7\%D9\%8A\%D8\%A7 \%D8\%A7\%D9\%84\%D8\%B4\%D9\%85\%D8\%B3\%D9\%8A

\% $8 \%$ A9

[22] N. Cekic; D. Milosavljevic, T. Pavlovic \& D. Mirjanic (2015); “Application of Solar Cells Contemporary Architecture"; Contemporary Materials (Renewable energy sources), VI-2 (2015), P. 105.

[23] S. Hall; (2014); "Benefits of building integrated photovoltaics"; available at: https://www.reminetwork.com/articles/benefits-of-building-integrated-photovoltaics/, (Accessed 14-8-2019).

[24] Ø. Aschehoug, \& D. Bell (2006); "BP Solar Skin - a façade concept for a sustainable future"; SINTEF Civil and Environmental Engineering Architecture and Building Technology; P: 5. 
[25] PV magazine; (2012); "Building-integrated photovoltaics facilitate multifunctional solutions"; available at: https://www.pv-magazine.com/press-releases/building-integrated-photovoltaics-facilitate-multifunctionalsolutions_10008906/, (Accessed 19-8-2019).

[26] A. Griffths; (2017); "Shigeru Ban's La Seine Musicale incorporates a wall of moving solar panels"; available at: https://www.dezeen.com/2017/10/04/shigeru-ban-la-seine-musicale-music-complex-movingsolar-panel-wall-paris-france/, (Accessed 19-8-2019).

[27] M. Corradi; (2016); "ANMA: Hexagone Balard defense department, Paris"; available at: https://www.floornature.com/anma-hexagone-balard-defence-department-paris-11637/, (Accessed 19-82019).

[28] F. Castro; (2018); "New Ministry of Defense in Paris / ANMA"; available at: https://www.archdaily.com/887388/new-ministry-of-defense-in-paris-anma, (Accessed 19-8-2019).

[29] P. Heinstein, C. Ballif \& L. Emmanuelle; (2013); "Building integrated photovoltaics (BIPV): Review, Potentials, Barriers and Myths"; DE GRUYTER; P: 151.

[30] I. Lomholt; (2019); "Ministry of Defense Paris: Headquarters Building"; available at: https://www.earchitect.co.uk/paris/ministry-of-defense-paris, (Accessed 20-8-2019).

[31] D. Efurosibina, K. Anissa \& A. Hassan; (2017); "A Review on Building Integrated Photovoltaic Façade Customization Potentials"; MDPI; sustainability; P: 1,2,9.

[32] M. Bastanfard; (2018); "Controlling Air Pollution with the Use of Bio Facades (A solution to Control Air Pollution in Tehran"; Bagh-e Nazar, 15 (65): 29-44; P: 33.

[33] F. Qiu; (2013); "Integration of algae in architecture"; Architectural Engineering Lab 10. https://ar.wikipedia.org/wiki/\%D8\%B7\%D8\%AD\%D8\%A7\%D9\%84\%D8\%A8 [3 [3الب، منو اجدة في:

[35] K-H Kim; (2013); "Beyond Green: Growing Algae Facade"; EPA Grant Number:SU835322.; P: 2.

[36] K-H Kim \& S. Patel; (2018); "Sustainable tall buildings: Microalgae Facades for City's Energy Production, Water Conservation, and Good Air Quality"; Proceedings of 125th IASTEM International Conference, Seoul, South Korea; P: 55.

[37] ecologiStudio; (2015); "Algae Folly: BioCities / algae / architecture / cyber-Gardens / food / responsive systems $\quad /$ soft cladding"; available at: http://www.ecologicstudio.com/v2/project.php?idcat=3\&idsubcat=71\&idproj=147, (Accessed 11-8-2019).

[38] K-H Kim; (2013); "Climate Change: Sustainability Performance of a Bio-façade for a Retrofitted Building"; EPA Grant Number:SU835322..

[39] A. Vidyasagar; (2016); "What Are Algae"; available at: https://www.livescience.com/54979-what-arealgae.html, (Accessed 7-8-2019).

[40] K-H Kim, \& M. Parrow (2013); "Project-based Learning: Interdisciplinary Collaboration of Biofacades in Urban Environment"; EPA Grant Number:SU835322.

[41] K. Lofgren; (2013); "World's First Algae-Powered Building by Splitterwerk Architects Opens in Germany"; available at https://inhabitat.com/splitterwerk-architects-design-worlds-first-algae-poweredbuilding-for-germany/, (Accessed 12-8-2019).

[42] L. Hadba; L. T. Silva \& P. Mendonca; (2017); "Green Walls an Efficient Solution for Hygrothermal, Noise and Air Pollution Control in the Buildings"; Living and Sustainability: An Environmental Critique of Design and Building Practices, Locally and Globally; P: 243.

[43] Islington; (2013); "Green roofs and walls - Good Practice Guide 1"; available at: https://www.islington.gov.uk/publicrecords/library/Planning-and-building-control/Publicity/Publicconsultation/2012-2013/(2012-12-20)-Good-Practice-Guide-1-Green-roofs-and-walls.pdf, (Accessed 27-82019).

[45] Growing Green Guide; "Green wall definition"; available at: https://www.growinggreenguide.org/technical-guide/introduction-to-roofs-walls-and-facades/green-walldefinition/, (Accessed 27-8-2019).

[46] A. Teicu; (2011); "Largest Living Wall in North America: Semiahmoo Library Green Wall"; available at: https://freshome.com/2011/09/01/largest-living-wall-in-north-america-semiahmoo-library-green-wall/, (Accessed 1-9-2019). 
[47] L. Wang; (2016); "Armenia's first BREEAM-certified building is an earthquake-resistant international school"; available at: https://inhabitat.com/armenias-first-breeam-certified-building-is-anearthquake-resistant-international-school/uwc-dilijan-college-by-tim-flynn-architects-13-2, (Accessed 2-92019).

[48] I. Block; (2018); "WOHA creates green community for senior citizens with Kampung Admiralty in Singapore"; available at: https://www.dezeen.com/2018/12/07/kampung-admiralty-woha-singapore-worldbuilding-year/, (Accessed 1-9-2019).

[49] UWC Dilijan College: 3D Tour- Одноклассники; available at: https://ok.ru/video/5081534897, (Accessed 2-9-2019).

[50] Novostink; available at: https://video.novostink.ru/video/kDxWhlOhSOI?id=0, (Accessed 2-9-2019).

[51] F. Castro; (2018); "Kampung Admiralty / WOHA"; available at: https://www.archdaily.com/904646/kampung-admiralty-woha, (Accessed 1-9-2019).

[52] Sustainable Water Management Wiki; "Green Roofs and Walls: the Technology, Benefits, and Design of Living Architecture"; available https://sustwatermgmt.fandom.com/wiki/Green_Roofs and_Walls: the Technology, Benefits, and_Design of Living Architecture, (Accessed 25-8-2019).

[53] P. Downton; (2013); "Materials Green roofs and walls"; YourHome.

[54] P. M. ŽIVKOVI]; D. G. DIMITRIJEVI] \& Ž. Ž. STEVANOVI]; (2018); "The Impact of The Building Envelope with The Green Lining Systems on The Built Environment"; THERMAL SCIENCE: Vol. 22, Suppl. 4; P: 1039-1041.

[55] S. Petkute; (2015); "Recycled Materials in Architecture. History of use, current projects and thoughts on future improvement"; available at: https://www.grin.com/document/317427, (Accessed 29-7-2019).

[56] NBM\&CW, Infra Construction \& Equipment; (2011); "Infrastructure Construction with Recycled Materials"; available at: https://www.nbmcw.com/tech-articles/others-article/25787-infrastructureconstruction-with-recycled-materials.html, (Accessed 29-7-2019).

[57] Domus; (2012); "Stephane Malka: Ame-Lot"; available at: https://www.domusweb.it/en/news/2012/02/29/stephane-malka-ame-lot.html, (Accessed 27-7-2019).

[58] J. Mairs; (2016); "Fifteen tonnes of rubble used to build Rotterdam house by Architectuur Maken"; available at: https://www.dezeen.com/2016/09/19/architectuur-maken-15-tonnes-rubble-recycled-rotterdamhouse/, (Accessed 24-7-2019).

[59] V. Sumateja Reddy; (2016); "Recycled and Recyclable Content Green Materials for Buildings - for Climate Protection"; International Journal of Engineering Sciences \& Research Technology; P: 656, 657.

[60] T. Metcalf; (2011); "Recycling +Building Materials"; available at: https://www.archdaily.com/155549/recyclingbuilding-materials, (Accessed 24-7-2019).

[61] Institute of Development Studies; (2016); "Ten Frontier Technologies for International DevelopmentClean Energy and Air Technology Reviews"; Institute of Development Studies; p: 112.

[62]A. Mansour; \& S.K. Al-Dawery; (2017); "Sustainable self-cleaning treatments for architectural facades in developing countries"; Alexandria Engineering Journal, ELSEVER; P: 3.

[63] S. Leydecker; (2008); "Nano Materials: in Architecture, Interior Architecture and Design"; Springer Science \& Business Media; P: 78, 79.

[64] S. Singh-Kurtz; (2018); "This NYC Luxury Building has the Air-Purifying Power of 500 Trees"; available at: https://qz.com/quartzy/1269569/this-nyc-luxury-building-has-the-air-purifying-power-of-500trees/, (Accessed 22-7-2019).

[65] C. Olson; (2018); "This New York City Building's Façade Actually Cleans the Air"; available at: https://www.architecturaldigest.com/story/new-york-city-building-facade-cleans-air, (Accessed 22-7-2019).

[66] Muhammad Ali Center; available at: https://2x4.org/work/muhammad-ali-center/, (Accessed 22-7-2019).

[67] 570 Broome; (2018); available at: https://570broome.com/, (Accessed 22-7-2019).

[68] G. Topličić-Ćurčić; D. Jevtić; D. Grdić; N. Ristić \& Z. Grdić; (2017); "Photocatalytic Concrete Environment Friendly Material"; 5th International Conference Contemporary achievements in civil engineering, Subotica, Serbia; P: 395, 399. 
Hala Adeeb / Engineering Research Journal 165 (March 2020) A1-A21

[69] S. Martin; (2000); “Green Building With Recycled Materials"; available at: https://www.motherearthnews.com/green-homes/green-building-with-recycled-materials-zmaz00jjzgoe/, (Accessed 22-8-2019). 